\title{
PEMODELAN PRODUKSI BAWANG MERAH DI JAWA TENGAH DENGAN MENGGUNAKAN HYBRID AUTOREGRESSIVE INTEGRATED MOVING AVERAGE - ADAPTIVE NEURO FUZZY INFERENCE SYSTEM
}

\author{
Inas Husna Diarsih ${ }^{1}$, Tarno $^{2}$, Agus Rusgiyono ${ }^{3}$ \\ 1,2,3 Departemen Statistika, Fakultas Sains dan Matematika, Universitas Diponegoro \\ e-mail :tarno.stat@gmail.com
}

\begin{abstract}
Red onion is one of the strategic horticulture commodities in Indonesia considering its function as the main ingredients of the basic ingredients of Indonesian cuisine. In an effort to increase production to supply national necessary, Central Java as the main center of red onion production should be able to predict the production of several periods ahead to maintain the balance of national production. The purpose of this research is to get the best model to forecast the production of red onion in Central Java by ARIMA, ANFIS, and hybrid ARIMA-ANFIS method. Model accuracy is measured by the smallest RMSE and AIC values. The results show that the best model to modeling red onion production in Central Java is obtained by hybrid ARIMA-ANFIS model which is a combination between SARIMA ([2], 1, [12]) and residual ARIMA using ANFIS model with input $e_{t, 1}, e_{t, 2}$ on the grid partition technique, gbell membership function, and membership number of 2 that produce RMSE 12033 and AIC 21.6634. While ARIMA model yield RMSE 13301,24 and AIC 21,89807 with violation of assumption. And the ANFIS model produces RMSE 14832 and AIC 22,0777. This shows that ARIMA-ANFIS hybrid method is better than ARIMA and ANFIS.
\end{abstract}

Keywords: production of red onion, ARIMA, ANFIS, hybrid ARIMA-ANFIS

\section{PENDAHULUAN}

Sektor pertanian memiliki peran penting yang berpengaruh terhadap pertumbuhan ekonomi di Indonesia. Sebagai sektor penyedia bahan pangan dan bahan baku industri, permintaan masyarakat pada sektor ini akan terus meningkat sejalan dengan peningkatan jumlah penduduk, kebutuhan, dan konsumsi masyarakat. Meningkatnya permintaan mengharuskan pemerintah melakukan perencanaan upaya khusus dalam peningkatan produksi pangan.

Salah satu dari tujuh komoditas strategis nasional dalam upaya khusus peningkatan produksi adalah bawang merah, karena fungsinya sebagai bahan utama bumbu dasar masakan Indonesia. Empat provinsi di Indonesia merupakan sentra produksi bawang merah, salah satunnya yakni Jawa Tengah. Sehingga Jawa Tengah harus mampu meramalkan produksi beberapa periode ke depan agar pemerintah Jawa Tengah memiliki gambaran yang jelas dalam melakukan perencanaan upaya khusus tersebut untuk menjaga keseimbangan produksi baik dalam pemenuhan kebutuhan sendiri maupun wilayahwilayah lain di Indonesia.

Salah satu metode peramalan tradisional yang sering digunakan adalah Autoregressive Integrated Moving Average (ARIMA). Kelemahan pada metode ini yakni asumsi stasioneritas dan kesulitan dalam penentuan orde (p,d,q) (Faulina dan Suhartono, 2013). Tetapi seiring dengan perkembangan ilmu pengetahuan, terdapat salah satu metode bagian dari sistem pakar yaitu Adaptive Neuro Fuzzy Inference System (ANFIS) yang merupakan gabungan antara Artificial Neural Network (ANN) dan Fuzzy Inference System (FIS) (Jang et al., 1997). Penggunaan metode ANFIS tidak membutuhkan asumsi independen, homoskedastisitas, dan residual berdistribusi normal yang sering tidak dijumpai pada data sehingga metode ini dinilai sesuai untuk meramalkan data yang mempunyai nilai ekstrem (Faulina dan Suhartono, 2013). 
Pada penulisan Tugas Akhir ini menggunakan metode hybrid ARIMA-ANFIS untuk melakukan pemodelan produksi bawang merah di Jawa Tengah. Tujuan penulisan Tugas Akhir ini adalah untuk menentukan metode peramalan terbaik antara metode ARIMA, ANFIS, dan hybrid ARIMA-ANFIS untuk memodelkan produksi bawang merah di Jawa Tengah.

\section{TINJAUANPUSTAKA}

\subsection{Autoregressive Integrated Moving Average (ARIMA)}

Model ARIMA $(p, d, q)$ merupakan hasil penggabungan antara proses nonstasioner yang telah distasionerkan dengan $p$ dan $q$ menyatakan orde dari autoregressive dan moving average dan $d$ adalah orde dari differensi. Bentuk umum dari model ARIMA $(p, d, q)$ dalam Soejoeti (1987) dapat didefiniskan sebagai berikut

$$
\phi_{p}(B)(1-B)^{d} Z_{t}=\theta_{q}(B) a_{t}
$$

Model yang digunakan apabila data yang digunakan mengandung pola musiman adalah model Seasonal Autoregressive Integrated Moving Average (SARIMA). Secara umum bentuk model Seasonal Autoregressive Integrated Moving Average (SARIMA $\left.(\mathrm{p}, \mathrm{d}, \mathrm{q})(\mathrm{P}, \mathrm{D}, \mathrm{Q})^{\mathrm{s}}\right)$ adalah

$$
\phi_{p}(B) \Phi_{P}\left(B^{S}\right)(1-B)^{d}\left(1-B^{S}\right)^{D} Z_{t}=\theta_{q}(B) \Theta_{Q}\left(B^{S}\right) a_{t}
$$

dimana

$$
\begin{array}{ll}
\phi_{p}(B) & =1-\phi_{1} B-\phi_{2} B^{2}-\ldots-\phi_{p} B^{p} \\
\Phi_{P}\left(B^{S}\right) & =1-\Phi_{1} B^{S}-\Phi_{2} B^{2 S}-\ldots-\Phi_{P} B^{P S} \\
\theta_{q}(B) & =1-\theta_{1} B-\theta_{2} B^{2}-\ldots-\theta_{q} B^{q} \\
\Theta_{Q}\left(B^{S}\right) & =1-\Theta_{1} B^{S}-\Theta_{2} B^{2 S}-\ldots-\Theta_{Q} B^{Q S}
\end{array}
$$

Berdasarkan persamaan (2) dapat dirumuskan juga model subset ARIMA. Menurut Tarno (2013), model subset ARIMA merupakan bagian dari model ARIMA tergeneralisasi, sehingga tidak dapat dinyatakan dalam bentuk umum. Contoh model subset ARIMA $([1,5], 0,[1,12])$ dapat ditulis sebagai berikut :

$$
\left(1-\phi_{1} B-\phi_{5} B^{5}\right) Z_{t}=\left(1-\theta_{1} B-\theta_{12} B^{12}\right) a_{t}
$$

Dengan demikian model subset ARIMA merupakan model ARIMA dengan beberapa parameternya sama dengan nol.

Dalam penentuan model ARIMA digunakan metode Box-Jenkins yang terdiri dari beberapa tahapan, yaitu identifikasi, estimasi parameter, pemeriksaan diagnostik, dan peramalan.

\subsection{Adaptive Neuro Fuzzy Inference System (ANFIS)}

Kusumadewi dan Hartati (2006) mengatakan bahwa ANFIS adalah arsitektur yang secara fungsional sama dengan fuzzy rule base model Sugeno dan merupakan suatu metode yang mana dalam melakukan penyetelan aturan digunakan algoritma pembelajaran terhadap sekumpulan data dan juga memungkinkan aturan-aturan untuk beradaptasi.

Menurut Tarno et al. (2013), apabila diberikan dua input yang terdiri atas $Z_{t, 1}$ yakni $Z$ pada waktu t-1 dan $Z_{t, 2}$ yakni $Z$ pada waktu t-2 dan sebuah output $\hat{Z}_{t}$, maka berdasarkan asumsi pada dasar aturan Sugeno orde satu terdapat dua aturan yakni sebagai berikut :

Aturan 1 : if $Z_{t, 1}$ is $A_{1}$ and $Z_{t, 2}$ is $B_{1}$ then $Z_{t}^{(1)}=p_{1} Z_{t, 1}+q_{1} Z_{t, 2}+r_{1}$

Aturan 2 : if $Z_{t, 1}$ is $A_{2}$ and $Z_{t, 2}$ is $B_{2}$ then $Z_{t}{ }^{(2)}=p_{2} Z_{t, 1}+q_{2} Z_{t, 2}+r_{2}$ 
dengan $Z_{t, 1}$ is $A_{1}$ dan $Z_{t, 2}$ is $B_{1} ; Z_{t, 1}$ is $A_{2}$ dan $Z_{t, 2}$ is $B_{2}$ adalah premis (nonlinear), sedangkan $\quad Z_{t}^{(1)}=p_{1} Z_{t, 1}+q_{1} Z_{t, 2}+r_{1}$ dan $Z_{t}^{(2)}=p_{2} Z_{t, 1}+q_{2} Z_{t, 2}+r_{2}$ adalah konsekuen (linear). $p_{1}, p_{2}, q_{1}, q_{2}, r_{1}, r_{2}$ adalah parameter konsekuen (linear) dan $A_{1}, B_{1}, A_{2}, B_{2}$ adalah parameter premis (nonlinear).

Jika derajat pengaktifan (the firing strength) setiap aturan adalah $w_{1}$ dan $w_{2}$ untuk $Z_{t}^{(1)}$ dan $Z_{t}^{(2)}$ dengan output $\hat{Z}_{t}$, maka dapat dihitung sebagai berikut:

$$
\hat{Z}_{t}=\frac{w_{1} Z_{t}^{(1)}+w_{2} Z_{t}^{(2)}}{w_{1}+w_{2}}=\bar{w}_{1} Z_{t}^{(1)}{ }_{1}+\bar{w}_{2} Z_{t}^{(2)}
$$

Arsitektur jaringan ANFIS dengan dasar aturan di atas dapat dilihat pada Gambar 1.

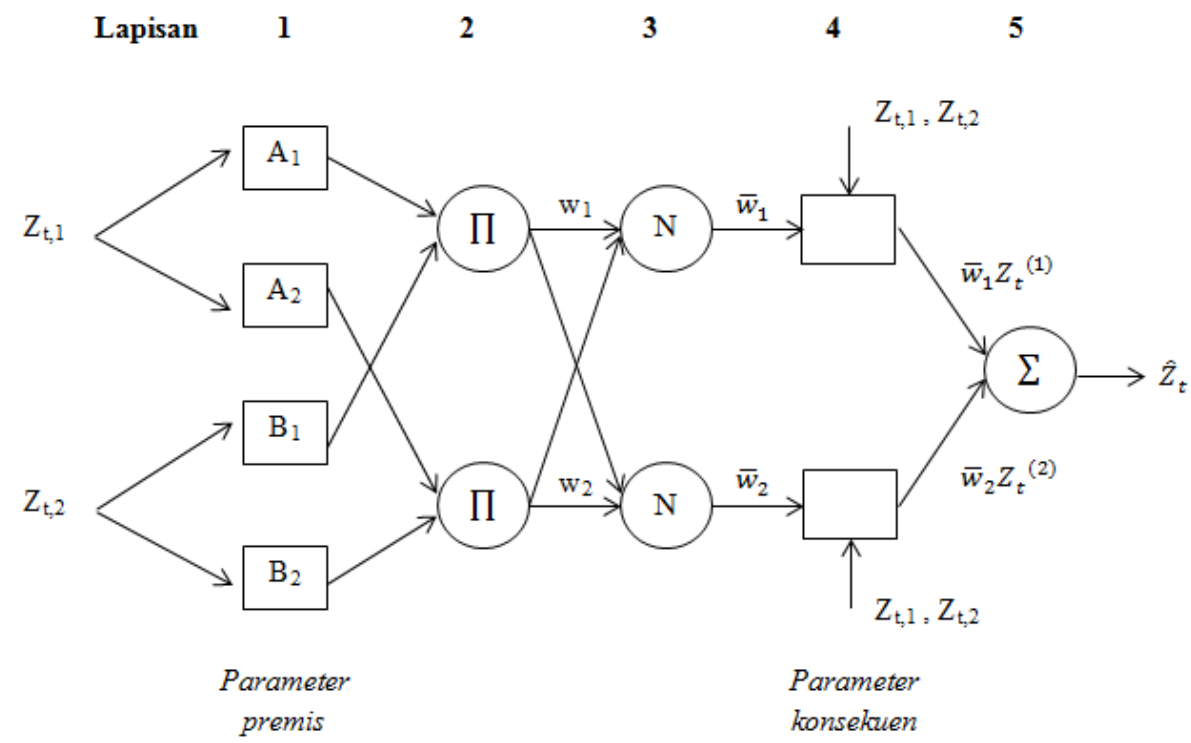

Gambar 1. Arsitektur Jaringan ANFIS

Menurut Jang et al. (1997), jaringan ANFIS terdiri dari lima lapisan (layer) yang memiliki masing-masing fungsi sebagai berikut:

\section{a. Lapisan 1 (Fuzzifikasi Input)}

Pada lapisan 1 tiap neuron adaptif terhadap parameter fungsi aktivasi. Output dari tiap neuron berupa derajat keanggotaan dari input yang diberikan oleh fungsi keanggotaan.

$$
\mu_{A_{1}}\left(Z_{t, 1}\right), \mu_{A_{2}}\left(Z_{t, 1}\right), \mu_{B_{1}}\left(Z_{t, 2}\right), \mu_{B_{2}}\left(Z_{t, 2}\right)
$$

Misalnya, diberikan fungsi keanggotaan yang diberikan adalah fungsi Generalized Bell (Gbell), yakni.

$$
\mu\left(Z_{t, i}\right)=\frac{1}{1+\left|\frac{Z-c}{a}\right|^{2 b}}, i=1,2
$$

dengan $Z$ adalah input dan $\{a, b$, dan $c\}$ adalah parameter premis.

b. Lapisan 2 (Operasi Logika Fuzzy)

Setiap neuron pada lapisan kedua berupa neuron non adaptif yang disimbolkan dengan $\Pi$. Output setiap neuron dalam lapisan ini menyatakan derajat pengaktifan tiap aturan (the firing strength of a rule) yang disimbolkan dengan $w_{i}$ dari aturan ke- $i$ dan dinyatakan dalam rumus sebagai berikut:

$$
w_{i}=\mu_{A_{i}}\left(Z_{t, 1}\right) \cdot \mu_{B_{i}}\left(Z_{t, 2}\right), i=1,2
$$




\section{c. $\quad$ Lapisan 3 (Normalized Firing Strength)}

Setiap neuron pada lapisan ketiga berupa non adaptif yang disimbolkan dengan $\mathbf{N}$. Output setiap neuron berupa derajat pengaktifan ternormalisasi (the normalized firing strength) yang disimbolkan dengan $\bar{w}_{i}$.

$$
\bar{w}_{i}=\frac{w_{i}}{w_{1}+w_{2}}, i=1,2
$$

\section{d. Lapisan 4 (Defuzzifikasi)}

Setiap neuron pada lapisan keempat berupa neuron adaptif. Output setiap neuron disimbolkan dengan $\bar{w}_{i} Z_{t}^{(i)}$.

$$
\bar{w}_{i} Z_{t}^{(i)}=\bar{w}_{i}\left(p_{i} Z_{t, 1}+q_{i} Z_{t, 2}+r_{i}\right)
$$

dengan $\bar{w}_{i}$ adalah normalized firing strength pada lapisan ketiga dan $p_{i}, q_{i}$, dan $r_{i}$ adalah parameter konsekuen pada neuron tersebut.

\section{e. Lapisan 5 (Perhitungan Output)}

Pada lapisan ini neuron tunggal (diberi simbol $\Sigma$ ) yang merupakan hasil penjumlahan seluruh output dari lapisan keempat, sebagai berikut:

$$
\begin{aligned}
& \hat{Z}_{t}=\sum_{i=1}^{2} \bar{w}_{i} Z_{t}^{(i)} \\
& \hat{Z}_{t}=\sum_{i=1}^{2} \bar{w}_{i}\left(p_{i} Z_{t, 1}+q_{i} Z_{t, 2}+r_{i}\right) \\
& \hat{Z}_{t}=\bar{w}_{1}\left(p_{1} Z_{t, 1}+q_{1} Z_{t, 2}+r_{1}\right)+\bar{w}_{2}\left(p_{2} Z_{t, 1}+q_{2} Z_{t, 2}+r_{2}\right) \\
& \hat{Z}_{t}=p_{1}\left(\bar{w}_{1} Z_{t, 1}\right)+q_{1}\left(\bar{w}_{1} Z_{t, 2}\right)+r_{1} \bar{w}_{1}+p_{2}\left(\bar{w}_{2} Z_{t, 1}\right)+q_{2}\left(\bar{w}_{2} Z_{t, 2}\right)+r_{2} \bar{w}_{2}
\end{aligned}
$$

\subsection{Algoritma Pembelajaran Hybrid dalam ANFIS}

Menurut Jang et al. (1997), Adaptive Neuro Fuzzy Inference System (ANFIS) mengaplikasikan algoritma pembelajaran hibrida (hybrid) dalam sistemnya untuk mengidentifikasi parameter. Algoritma pembelajaran hibrida akan mengatur parameterparameter konsekuen $p_{i}, q_{i}$, dan $r_{i}$ secara maju (forward) diidentifikasi menggunakan least square dan akan mengatur parameter-parameter premis secara mundur (backward) menggunakan metode gradient descent.

\subsection{Hybrid ARIMA-ANFIS}

Model hibrida (hybrid) adalah suatu metode kombinasi dari satu atau lebih model dalam fungsi suatu sistem. Menurut Zhang (2003), secara umum kombinasi model runtun waktu yang memiliki struktur linier dan non-linier dapat dituliskan sebagai berikut:

$$
Z_{t}=L_{t}+N_{t}
$$

dimana $L_{t}$ menunjukkan komponen linier dan $N_{t}$ menunjukkan komponen non-linier. Model ARIMA digunakan untuk menyelesaikan kasus yang linier, dimana residual dari model yang linier masih mengandung informasi hubungan non-linier. Secara matematis dapat dituliskan sebagai berikut :

$$
e_{t}=Z_{t}-\hat{L}_{t}
$$

dimana $\hat{L}_{t}$ adalah nilai ramalan ARIMA pada waktu $t$ dan $Z_{t}$ adalah data awal waktu ke- $t$. Kemudian memodelkan residual dari model ARIMA menggunakan ANFIS maka hubungan non-linier dapat teratasi. Hasil ramalan ANFIS kemudian dikombinasikan 
dengan hasil ramalan metode ARIMA. Secara matematis, hasil ramalan keseluruhan yang diperoleh adalah sebagai berikut:

$$
\hat{Z}_{t}=\hat{L}_{t}+\hat{N}_{t}
$$

dimana $\hat{N}_{t}$ adalah ramalan dari Persamaan (10) dan $\hat{Z}_{t}$ adalah hasil peramalan dari gabungan nilai ramalan model ARIMA dan nilai ramalan model ANFIS.

\subsection{Pemilihan Model Terbaik}

a. Akaike's Information Criterion (AIC)

AIC digunakan untuk memilih model terbaik dengan mempertimbangkan jumlah parameter dalam model dimana semakin kecil nilai AIC, maka model semakin baik dan layak untuk digunakan. Menurut Wei (2006), AIC dapat didefinisikan sebagai berikut: dengan$$
\text { AIC }(M)=-2 \ln (\text { maximum likelihood })+2 M
$$

$$
\ln \hat{L}=-\frac{n}{2} \ln \hat{\sigma}_{a}^{2}-\frac{n}{2}(1+\ln 2 \pi)
$$

dimana $M$ adalah banyak parameter dari model ARMA dan $n$ adalah banyak pengamatan

\section{b. Root Mean Square Error (RMSE)}

Pemilihan model terbaik dalam peramalan juga ditentukan oleh error yang dihasilkan yakni dengan RMSE.

$$
R M S E=\sqrt{\frac{\sum_{t=1}^{n} e_{t}^{2}}{n}}=\sqrt{\frac{\sum_{t=1}^{n}\left(Z_{t}-\hat{Z}_{t}\right)^{2}}{n}}
$$

dengan $e_{t}$ adalah residual pada periode t, $Z_{t}$ adalah data aktual pada periode $\mathrm{t}$, dan $\hat{Z}_{t}$ adalah data hasil prediksi pada periode $\mathrm{t}$

\section{METODOLOGI PENELITIAN}

\subsection{Sumber Data dan Variabel Penelitian}

Data yang digunakan merupakan data sekunder mengenai produksi bawang merah di Jawa Tengah pada tahun 2006 sampai dengan 2016 yang diperoleh dari Dinas Pertanian dan Perkebunan Provinsi Jawa Tengah.Variabel data yang digunakan dalam penelitian ini adalah data produksi bawang merah di Jawa Tengah periode bulanan dari Januari 2006 sampai dengan Desember 2016 sebanyak 132 data yang digunakan untuk pemodelan.

\subsection{Metode Analisis Data}

Langkah - langkah peramalan dengan model hibrida ARIMA-ANFIS yakni sebagai berikut :

1. Pemodelan linear (ARIMA) meliputi beberapa tahapan yakni stasioneritas data, estimasi parameter, pemeriksaan diagnostik, menentukan nilai prediksi serta menghitung nilai AIC dan RMSE. Model ARIMA yang digunakan di pemodelan hibrida adalah model ARIMA terbaik.

2. Melakukan pemodelan dan peramalan dengan model ARIMA terbaik.

3. Pemodelan nonlinear (ANFIS) terdapat beberapa langkah yakni sebagai berikut:

a. Variabel input yang digunakan berdasarkan lag AR dari residual model ARIMA terbaik.

b. Menentukan banyaknya jumlah keanggotaan yakni 2 dan 3 serta fungsi keanggotaan yang akan digunakan yakni Gauss, Generalized Bell, Segitiga, dan Trapesium. 
c. Membagi input data yang bernilai crisp menjadi linguistik sesuai banyaknya kelompok dengan Grid Partition dan Fuzzy Cluster Mean.

d. Menentukan banyak iterasi (epoch) yang diinginkan.

e. Menjalankan pelatihan parameter fuzzy inference system yakni fuzzifikasi, operasi logika fuzzy, pengaktifan derajat ternormalisasi, dan defuzzifikasi.

4. Tahap kombinasi, yaitu menggabungkan langkah 1 dan 3 sehingga didapat model hibrida ARIMA-ANFIS

5. Melakukan peramalan data in sample dengan model hibrida ARIMA -ANFIS sehingga diperoleh ramalan hibrida ARIMA - ANFIS.

6. Menghitung nilai AIC dan RMSE

7. Memilih model terbaik berdasarkan nilai AIC dan RMSE terkecil

\section{HASIL DAN PEMBAHASAN}

\subsection{Analisis Data dengan Autoregressive Integrated Moving Average (ARIMA)}

Identifikasi model merupakan langkah awal dalam analisis menggunakan ARIMA yakni dengan membuat plot runtun waktu, ACF, dan PACF.

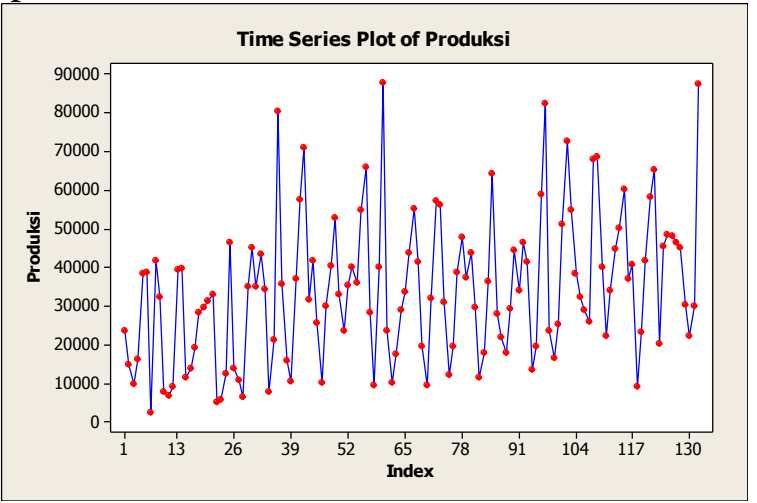

Gambar 2. Plot Runtun Waktu Data Produksi Bawang Merah

Berdasarkan Gambar 2, terlihat bahwa data produksi bawang merah di Jawa Tengah periode Januari 2006 hingga Desember 2016 belum stasioner dalam mean karena berpola trend naik dan terlihat dari sebaran plot yang tidak stabil dan sangat fluktuatif.
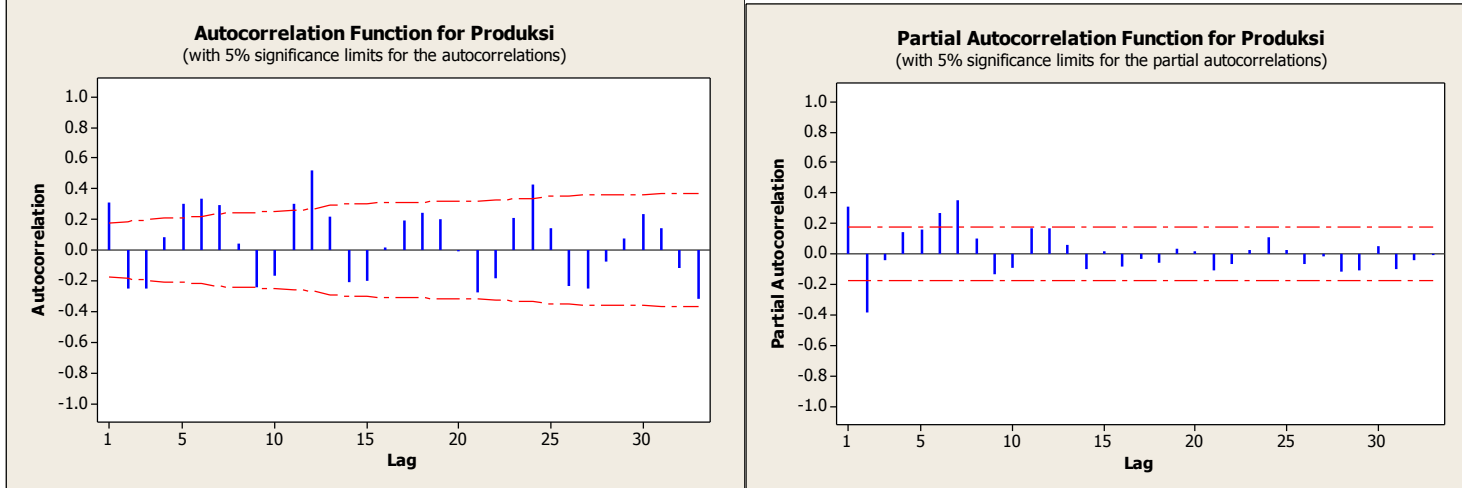

Gambar 3. Plot ACF dan PACF Produksi Bawang Merah

Selain itu, ketidakstasioneran juga dapat dilihat berdasarkan plot ACF dan PACF pada Gambar 3 dimana plot ACF menunjukkan bahwa lag cenderung membentuk gelombang sinus dan tiap lag kelipatan 12 terpotong oleh garis batas signifikan maka data belum stasioner. Sehingga perlu dilakukan differensi orde ke-1 untuk mengatasi pola non musiman dan orde ke-12 untuk mengatasi pola musiman setiap 12 bulan. Setelah dilakukan differensi non-musiman dan musiman, pada uji Dickey Fuller diperoleh nilai Prob $(0,0417)$ $<\alpha(0,05)$ maka proses telah stasioner dalam mean. Sehingga dapat disimpulkan bahwa 
data produksi bawang merah setelah dilakukan differensi sudah stasioner. Selain dilakukan uji stasioneritas secara formal perlu dilakukan uji stasioneritas secara visual. Berdasarkan plot runtun waktu pada Gambar 4 menunjukkan bahwa data telah stasioner karena sebaran plot sudah stabil dan tidak terdapat trend. Serta plot ACF dan PACF pada Gambar 5 juga terlihat bahwa data telah stasioner karena turun secara eksponensial setelah lag $q$ dan $p$.

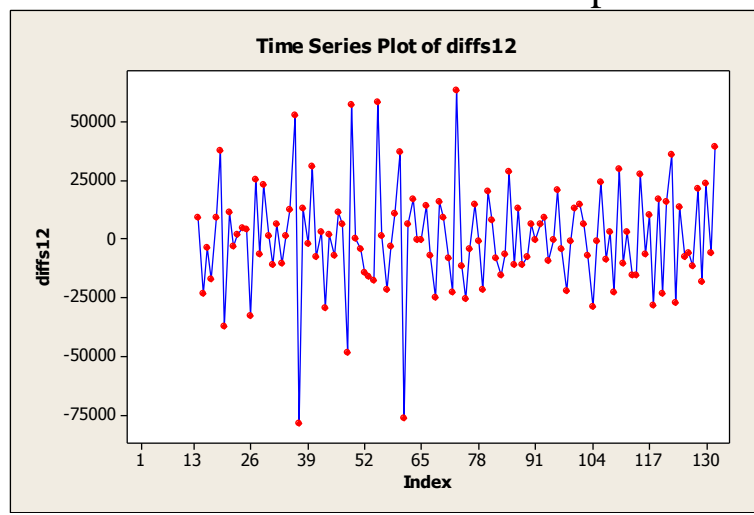

Gambar 4. Plot Runtun Waktu Setelah Differensi
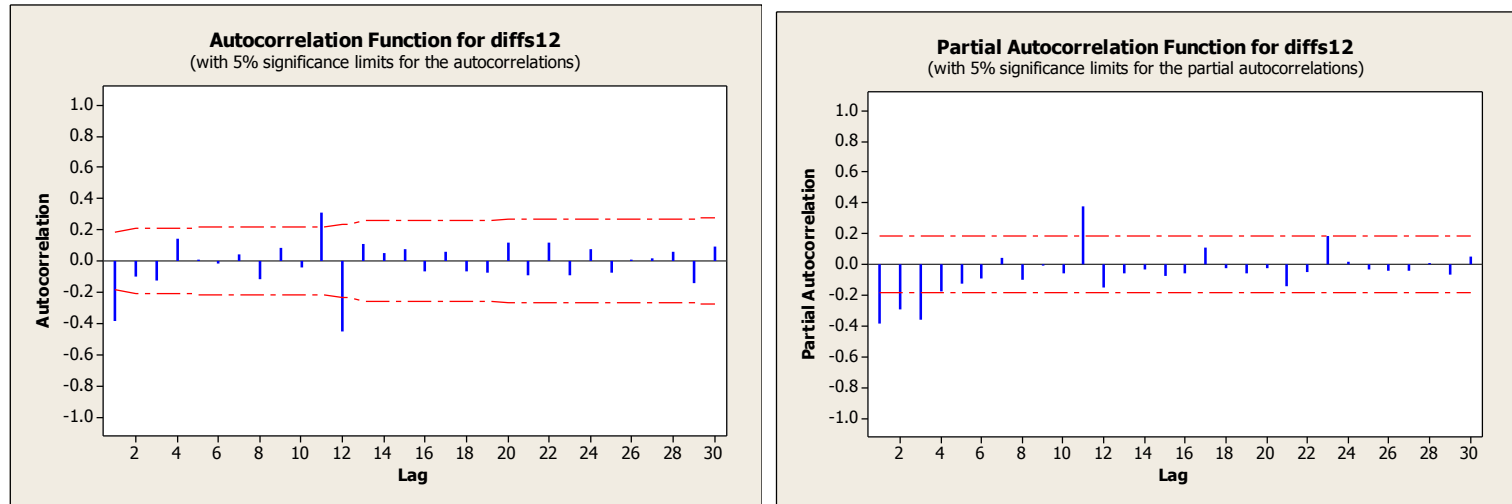

Gambar 5. Plot ACF dan PACF setelah Differnsi

Setelah asumsi stasioneritas secara visual dan formal terpenuhi, maka berdasarkan Gambar 5 diduga model runtun waktu dengan melihat plot ACF dan PACF. Plot ACF menunjukkan cut off pada lag 1, 11 dan lag musiman yaitu lag 12. Sedangkan plot PACF menunjukkan cut off pada lag 1, 2, 3, 11, dan 23. Dari beberapa pendugaan model diperoleh model terbaik yakni SARIMA ([1,2,3],1,[12]) dengan nilai RMSE dan AIC terkecil, dengan persamaan sebagai berikut:

$$
\begin{aligned}
Z_{t}= & 0,385 Z_{t-1}+0,079 Z_{t-2}+0,165 Z_{t-3}+0,371 Z_{t-4}+a_{t}+0,884 a_{t-12} \\
& \multicolumn{1}{c}{\text { Tabel 1. Ringkasan Analisis Model ARIMA Terbaik }} \\
\hline & \text { Pengujian } \\
\text { Uji signifikansi parameter } & \phi_{1}, \phi_{2}, \phi_{3}, \theta_{12} \text { signifikan } \\
\text { Uji independensi residual } & \text { Terpenuhi } \\
\text { Uji normalitas residual } & \text { Terpenuhi } \\
\text { Uji homoskedastisitas residual } & \text { Tidak Terpenuhi } \\
\text { RMSE } & 13301,24 \\
\text { AIC } & 21,89807
\end{aligned}
$$

Berdasarkan Tabel 1 menunjukkan bahwa model SARIMA $([1,2,3], 1,[12])$ tidak dapat digunakan untuk memodelkan produksi bawang merah di Jawa Tengah karena tidak memenuhi asumsi homoskedastisitas residual atau terdapat efek ARCH/ GARCH pada residual. 


\subsection{Analisis Data dengan Hybrid ARIMA-ANFIS}

Berdasarkan analisis ARIMA diperoleh model terbaik adalah SARIMA $([1,2,3], 1,[12])$. Karena model SARIMA ([1,2,3],1,[12]) memiliki parameter yang cukup banyak maka dapat dibentuk model sesuai prinsip parsimony (Soejoeti,1987) yang menyatakan model yang lebih sederhana lebih disenangi daripada model dengan parameter yang banyak.yakni model SARIMA ([2],1,[12]), sehingga model SARIMA yang dibentuk sebagai berikut:

$$
Z_{t}=Z_{t-1}+\phi_{2} Z_{t-2}-\phi_{2} Z_{t-3}+a_{t}-\theta_{12} a_{t-12}
$$

Plot PACF dari residual dari model SARIMA ([2],1,[12]) tersebut digunakan untuk melihat lag yang cut off. Berdasarkan Gambar 6, dapat dilihat bahwa pada plot PACF terdapat lag yang cut off pada lag 1,2, dan 3. Maka digunakan beberapa kombinasi dari lag 1, 2, dan 3 sebagai input pada pemodelan ANFIS untuk meramalkan residual dari model model SARIMA ([2],1,[12]).

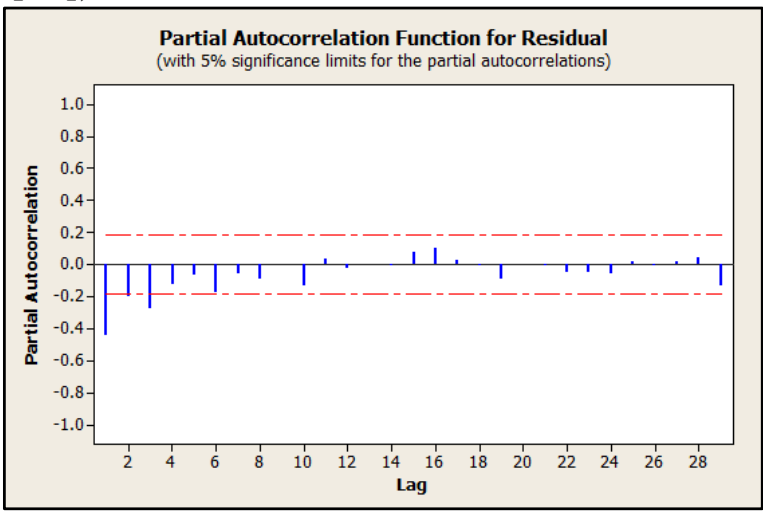

Gambar 6. Plot PACF Residual SARIMA ([2],1,[12])

Setelah menentukan input yang digunakan, kemudian menentukan fungsi keanggotaan yang akan digunakan yakni gauss, generalized bell (gbell), segitiga, dan trapesium dengan jumlah keanggotaan sebanyak 2 dan 3 dengan dua teknik pengklasteran yakni Fuzzy C-Means (FCM) dan grid partition. Hasil dari kedua teknik tersebut adalah sebagai berikut :

\section{a. Teknik FCM}

Pada teknik FCM fungsi keanggotaan (FK) yang digunakan merupakan fungsi default yakni gauss. Jumlah aturan pada teknik ini sama dengan jumlah keanggotaan yang ditentukan, maka tidak ada kombinasi dalam pembentukan aturan.

Tabel 2. Nilai RMSE dan AIC Model Hybrid ARIMA-ANFIS Teknik FCM

\begin{tabular}{cccccc}
\hline \multirow{2}{*}{ Input } & \multirow{2}{*}{ FK } & \multicolumn{2}{c}{ Jumlah Keanggotaan 2 } & \multicolumn{2}{c}{ Jumlah Keanggotaan 3 } \\
\cline { 3 - 6 } & & RMSE & AIC & RMSE & AIC \\
\hline$e_{t, 1}$ & & 13630 & 21,8951 & 13148 & 21,8232 \\
$e_{t, 2}$ & & 16057 & 22,2231 & 15331 & 22,1306 \\
$e_{t, 3}$ & 15895 & 22,2029 & 15310 & 22,1279 \\
$e_{t, 1,}, e_{t, 2}$ & \multirow{2}{*}{ Gauss } & 13604 & 21,9089 & 13385 & 21,8765 \\
$e_{t, 1}, e_{t, 3}$ & & 13627 & 21,9126 & 13192 & 21,8478 \\
$e_{t, 2}, e_{t, 3}$ & & 15769 & 22,2046 & 15446 & 22,1632 \\
$e_{t, 1}, e_{t, 2,}, e_{t, 3}$ & & 13174 & 21,8625 & 15446 & 22,1807 \\
\hline
\end{tabular}

Berdasarkan pada Tabel 2 dan sesuai dengan prinsip parsimony, dapat disimpulkan bahwa model hybrid ARIMA-ANFIS terbaik yakni pada jumlah keanggotaan 2 fungsi keanggotaan Gauss dengan input $e_{t, 1}, e_{t, 2}, e_{t, 3}$. 


\section{b. Teknik Grid Partition}

Pada teknik Grid Partition fungsi keanggotaan (FK) yang digunakan yakni gauss, generalized bell (gbell), segitiga, dan trapesium. Setiap aturan yang terbentuk pada teknik ini merupakan kombinasi dari tingkat partisi untuk setiap input.

Tabel 3. Nilai RMSE dan AIC Model Hybrid ARIMA-ANFIS Teknik Grid Partition

\begin{tabular}{|c|c|c|c|c|c|}
\hline \multirow{2}{*}{ Input } & \multirow{2}{*}{ FK } & \multicolumn{2}{|c|}{ Jumlah Keanggotaan 2} & \multicolumn{2}{|c|}{ Jumlah Keanggotaan 3} \\
\hline & & RMSE & AIC & RMSE & AIC \\
\hline$e_{t, 1}$ & & 13625 & 21,8944 & 13309 & 21,8475 \\
\hline$e_{t, 2}$ & & 16065 & 22,2240 & 15418 & 22,1419 \\
\hline$e_{t, 3}$ & & 16001 & 22,2162 & 15695 & 22,1776 \\
\hline$e_{t, 1}, e_{t, 2}$ & Gauss & 12104 & 21,6752 & 11709 & 21,6088 \\
\hline$e_{t, 1,} e_{t, 3}$ & & 13435 & 21,8842 & 12380 & 21,7206 \\
\hline$e_{t, 2,} e_{t, 3}$ & & 15035 & 22,1093 & 14180 & 21,9922 \\
\hline$e_{t, 1,}, e_{t, 2,}, e_{t, 3}$ & & 12921 & 21,8238 & 35491 & 23,8446 \\
\hline$e_{t, 1}$ & & 13659 & 21,8995 & 13207 & 21,8322 \\
\hline$e_{t, 2}$ & & 15929 & 22,2071 & 15352 & 22,1332 \\
\hline$e_{t, 3}$ & & 15992 & 22,2151 & 15629 & 22,1692 \\
\hline$e_{t, 1,} e_{t, 2}$ & Gbell & 12033 & 21,6634 & 11846 & 21,6322 \\
\hline$e_{t, 1}, e_{t, 3}$ & & 13414 & 21,8810 & 12290 & 21,7060 \\
\hline$e_{t, 2,}, e_{t, 3}$ & & 14879 & 22,0884 & 14059 & 21,9749 \\
\hline$e_{t, 1}, e_{t, 2,}, e_{t, 3}$ & & 11545 & 21,5985 & 40142 & 24,0909 \\
\hline$e_{t, 1}$ & & 13602 & 21,8910 & 13461 & 21,8702 \\
\hline$e_{t, 2}$ & & 16073 & 22,2251 & 15564 & 22,1607 \\
\hline$e_{t, 3}$ & & 16004 & 22,2166 & 15752 & 22,1849 \\
\hline$e_{t, 1}, e_{t, 2}$ & Segitiga & 12542 & 21,7464 & 25161 & 23,1388 \\
\hline$e_{t, 1,}, e_{t, 3}$ & & 13081 & 21,8308 & 16577 & 22,3045 \\
\hline$e_{t, 2,}, e_{t, 3}$ & & 15626 & 22,1864 & 16116 & 22,2481 \\
\hline$e_{t, 1}, e_{t, 2,}, e_{t, 3}$ & & 24668 & 23,1170 & 80321 & 25,4781 \\
\hline$e_{t, 1}$ & & 13777 & 21,9166 & 13191 & 21,8297 \\
\hline$e_{t, 2}$ & & 16072 & 22,2249 & 15325 & 22,1297 \\
\hline$e_{t, 3}$ & & 15943 & 22,2089 & 15651 & 22,1720 \\
\hline$e_{t, 1}, e_{t, 2}$ & Trapesium & 12696 & 21,7707 & 12056 & 21,6673 \\
\hline$e_{t, 1,} e_{t, 3}$ & & 13459 & 21,8878 & 12709 & 21,7730 \\
\hline$e_{t, 2,} e_{t, 3}$ & & 15315 & 22,1461 & 14729 & 22,0682 \\
\hline$e_{t, 1,} e_{t, 2,} e_{t, 3}$ & & 11646 & 21,6160 & 10204 & 21,3516 \\
\hline
\end{tabular}

Berdasarkan pada Tabel 3 dan sesuai dengan prinsip parsimony, dapat disimpulkan bahwa model hybrid ARIMA-ANFIS terbaik yakni pada jumlah keanggotaan 2 fungsi keanggotaan gbell dengan input $e_{t, 1}, e_{t, 2}$.

Berdasarkan Tabel 2 dan 3, dilakukan perbandingan model hybrid ARIMA-ANFIS terbaik antara teknik FCM dan teknik grid partition.

Tabel 4. Perbandingan Nilai RMSE dan AIC Model Hybrid ARIMA-ANFIS

\begin{tabular}{cccccc}
\hline Teknik & Input & FK & $\begin{array}{c}\text { Jumlah } \\
\text { Keanggotaan }\end{array}$ & RMSE & AIC \\
\hline FCM & $e_{t, 1,}, e_{t, 2,}, e_{t, 3}$ & Gauss & 2 & 13174 & 21,8625 \\
Grid Partition & $e_{t, 1,}, e_{t, 2}$ & Gbell & 2 & 12033 & 21,6634 \\
\hline
\end{tabular}

Berdasarkan Tabel 4, dapat disimpulkan bahwa dapat disimpulkan bahwa model hybrid ARIMA-ANFIS terbaik pada Tugas Akhir ini yakni menggunakan teknik grid partition dengan input yakni $e_{t, 1}, e_{t, 2}$ fungsi keanggotaan gbell dan jumlah keanggotaan sebanyak 2 . 
Berdasarkan model hybrid ARIMA- ANFIS terbaik, dapat dilihat perbandingan data target dan data output pada Gambar 7.

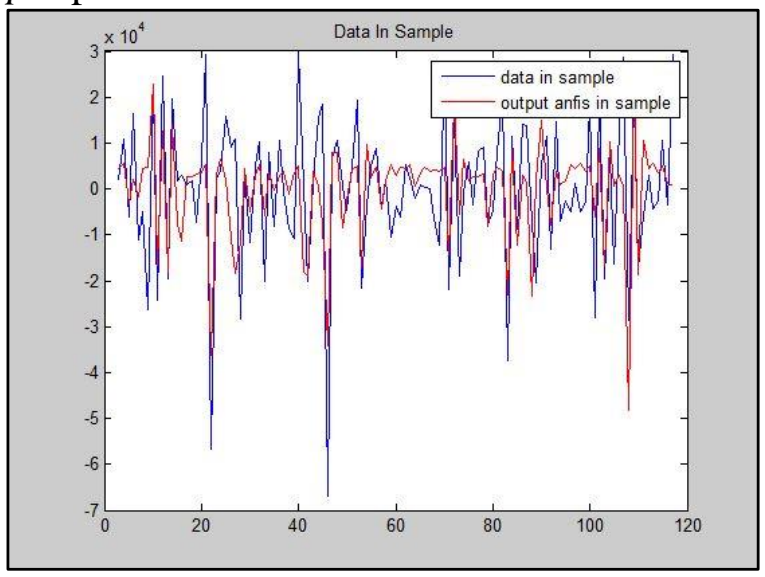

Gambar 7. Perbandingan Target dan Output Hybrid ARIMA-ANFIS Terbaik

Pemodelan hybrid ARIMA - ANFIS terbaik menggunakan teknik grid partition dengan input sebanyak 2 dan jumlah keanggotaan sebanyak 2 sehingga terbentuk 4 aturan sebagai berikut :

1. if $e_{t, 1}$ is $A_{1}$ and $e_{t, 2}$ is $B_{1}$ then $e_{t}^{(1)}=p_{1} e_{t, 1}+q_{1} e_{t, 2}+r_{1}$

2. if $e_{t, 1}$ is $A_{1}$ and $e_{t, 2}$ is $B_{2}$ then $e_{t}^{(2)}=p_{2} e_{t, 1}+q_{2} e_{t, 2}+r_{2}$

3. if $e_{t, 1}$ is $A_{2}$ and $e_{t, 2}$ is $B_{1}$ then $e_{t}{ }^{(3)}=p_{3} e_{t, 1}+q_{3} e_{t, 2}+r_{3}$

4. if $e_{t, 1}$ is $A_{2}$ and $e_{t, 2}$ is $B_{2}$ then $e_{t}^{(4)}=p_{4} e_{t, 1}+q_{4} e_{t, 2}+r_{4}$

dengan $A_{1}, B_{1}, A_{2}$, dan $B_{2}$ merupakan parameter premis atau nonlinear, sedangkan $p_{1}, p_{2}, \ldots, p_{4}, q_{1}, q_{2}, \ldots, q_{4}$, dan $r_{1}, r_{2}, \ldots, r_{4}$, merupakan parameter konsekuen atau linear.

Pada lapisan 1 dalam arsitektur ANFIS terdapat 4 kelompok nilai awal parameter nonlinear atau premis. Nilai awal parameter tersebut akan digunakan untuk proses pembelajaran sampai pada iterasi yang telah ditentukan, dalam penulisan Tugas Akhir ini digunakan iterasi sebanyak 50. Output yang dihasilkan pada lapisan 1 adalah fungsi keanggotaan pada tiap input untuk semua himpunan fuzzy yakni $\mu_{A_{1}}\left(e_{t, 1}\right), \mu_{A_{2}}\left(e_{t, 1}\right)$, $\mu_{B_{1}}\left(e_{t, 2}\right)$, dan $\mu_{B_{2}}\left(e_{t, 2}\right)$. Nilai fungsi keanggotaan tersebut akan digunakan sebagai input pada lapisan 2 dan menghasilkan derajat pengaktifan tiap aturan. Pada model ANFIS terbaik tersebut memiliki 4 aturan, maka output lapisan 2 berupa $w_{1}, w_{2}, \ldots, w_{4}$. Nilai $w_{i}$ yang diperoleh pada lapisan 2 akan digunakan sebagai input pada lapisan 3 untuk dilakukan normalisasi derajat pengaktifan aturan fuzzy dan output yang diperoleh yakni $\bar{w}_{1}, \bar{w}_{2}, \ldots \bar{w}_{4}$. Output lapisan 3 digunakan untuk proses defuzzifikasi pada lapisan 4, akan diperoleh pada nilai parameter premis atau nonlinear yang telah diperbaiki secara mundur dari lapisan 5 hingga lapisan 1 menggunakan konsep gradient descent pada pembelajaran model ANFIS terbaik. Selain parameter premis atau nonlinear, juga diperoleh parameter konsekuen atau linear yang didapatkan dari hasil pembelajaran Least Square Estimator (LSE) Rekursif. Parameter - parameter konsekuen tersebut dapat dilihat pada bentuk linear untuk setiap aturan sebagai berikut :

1. $e_{t}^{(1)}=-45,86 e_{t, 1}-1,837 e_{t, 2}-935400$

2. $e_{t}^{(2)}=4,686 e_{t, 1}+5,88 e_{t, 2}-30800$

3. $e_{t}{ }^{(3)}=-4,27 e_{t, 1}-0,8446 e_{t, 2}+229600$

4. $e_{t}^{(4)}=-1,86 e_{t, 1}-3,29 e_{t, 2}+35170$

Berdasarkan parameter konsekuen yang terbentuk, output lapisan 4 berupa $\bar{w}_{1} e_{t}{ }^{(1)}, \bar{w}_{2} e_{t}{ }^{(2)}, \ldots, \bar{w}_{4} e_{t}^{(4)}$. Pada lapisan 5, output dari lapisan 4 akan dijumlahkan dan diperoleh model sebagai berikut : 


$$
\begin{aligned}
\hat{e}_{t}= & \sum_{i=1}^{4} \bar{w}_{i} e_{t}^{(i)} \\
\hat{e}_{t}= & \sum_{i=1}^{4} \bar{w}_{i}\left(p_{i} e_{t, 1}+q_{i} e_{t, 2}+r_{i}\right) \\
\hat{e}_{t}= & \bar{w}_{1}\left(-45,86 e_{t, 1}-1,837 e_{t, 2}-935400\right)+\bar{w}_{2}\left(4,686 e_{t, 1}+5,88 e_{t, 2}-30800\right)+ \\
& \bar{w}_{3}\left(-4,27 e_{t, 1}-0,8446 e_{t, 2}+229600\right)+\bar{w}_{4}\left(-1,86 e_{t, 1}-3,29 e_{t, 2}+35170\right)
\end{aligned}
$$

dengan

$$
\begin{aligned}
& \bar{w}_{i}=\frac{w_{i}}{\sum_{i=1}^{4} w_{i}} \\
& \text { 1. } w_{1}=\mu_{A_{1}}\left(e_{t, 1}\right) \cdot \mu_{B_{1}}\left(e_{t, 2}\right)=\left(\frac{1}{1+\left|\frac{e_{t, 1}+67070}{48480}\right|^{3,336}}\right)\left(\frac{1}{1+\left|\frac{e_{t, 2}+67070}{48480}\right|^{3,738}}\right) \\
& \text { 2. } w_{2}=\mu_{A_{1}}\left(e_{t, 1}\right) \cdot \mu_{B_{2}}\left(e_{t, 2}\right)=\left(\frac{1}{1+\left|\frac{e_{t, 1}+67070}{48480}\right|^{3,336}}\right)\left(\frac{1}{1+\left|\frac{e_{t, 2}-29880}{48480}\right|^{4,794}}\right) \\
& \text { 3. } w_{3}=\mu_{A_{2}}\left(e_{t, 1}\right) \cdot \mu_{B_{1}}\left(e_{t, 2}\right)=\left(\frac{1}{1+\left|\frac{e_{t, 1}-29880}{48480}\right|^{2,648}}\right)\left(\frac{1}{1+\left|\frac{e_{t, 2}+67070}{48480}\right|^{3,738}}\right) \\
& \text { 4. } w_{4}=\mu_{A_{2}}\left(e_{t, 1}\right) \cdot \mu_{B_{2}}\left(e_{t, 2}\right)=\left(\frac{1}{1+\left|\frac{e_{t, 1}-29880}{48480}\right|^{2,648}}\right)\left(\frac{1}{1+\left|\frac{e_{t, 2}-29880}{48480}\right|^{4,794}}\right)
\end{aligned}
$$

Sehingga model hybrid ARIMA-ANFIS yang terbentuk merupakan gabungan dari model SARIMA ([2],1,[12]) dan residual ARIMA menggunakan model ANFIS dan dapat dituliskan secara matematis sebagai berikut: dengan

$$
Z_{t}=\widehat{L}_{t}+\widehat{N}_{t}
$$

$$
\begin{aligned}
\hat{L}_{t}= & Z_{t-1}-0,202 Z_{t-2}+0,202 Z_{t-3}+a_{t}+0,887 a_{t-12} \\
\widehat{N}_{t}= & \bar{w}_{1}\left(-45,86 e_{t, 1}-1,837 e_{t, 2}-935400\right)+\bar{w}_{2}\left(4,686 e_{t, 1}+5,88 e_{t, 2}-30800\right)+ \\
& \bar{w}_{3}\left(-4,27 e_{t, 1}-0,8446 e_{t, 2}+229600\right)+\bar{w}_{4}\left(-1,86 e_{t, 1}-3,29 e_{t, 2}+35170\right)
\end{aligned}
$$

\subsection{Pemilihan Model Terbaik}

Pemilihan model terbaik antara ARIMA, ANFIS, dan hybrid ARIMA-ANFIS diperoleh berdasarkan AIC dan RMSE terkecil. Perbandingan nilai AIC dan RMSE pada ARIMA, ANFIS, dan hybrid ARIMA-ANFIS terbaik dapat dilihat pada Tabel 5.

Tabel 5. Perbandingan Nilai AIC dan RMSE

\begin{tabular}{ccc}
\hline Model & AIC & RMSE \\
\hline ARIMA & 21,89807 & 13301,24 \\
ANFIS & 22,0777 & 14832 \\
Hybrid ARIMA-ANFIS & 21,6634 & 12033 \\
\hline
\end{tabular}

Berdasarkan Tabel 5, diperoleh bahwa diperoleh bahwa nilai RMSE dan AIC hybrid ARIMA - ANFIS lebih kecil dibandingkan ARIMA dan ANFIS, sehingga dapat disimpulkan bahwa analisis menggunakan hybrid ARIMA - ANFIS lebih baik daripada ARIMA dan ANFIS pada Tugas Akhir ini.

\section{KESIMPULAN}

Kesimpulan yang diperoleh pada Tugas Akhir ini bahwa model terbaik yang digunakan untuk memodelkan produksi bawang merah di Jawa Tengah adalah model hybrid ARIMA-ANFIS yakni gabungan dari model SARIMA ([2],1,[12]) dan residual ARIMA menggunakan model ANFIS yang menggunakan teknik grid partition dengan input yakni $e_{t, 1}, e_{t, 2}$ fungsi keanggotaan gbell dan jumlah keanggotaan sebanyak 2 , dengan bentuk persamaan sebagai berikut :

dengan

$$
Z_{t}=\widehat{L}_{t}+\widehat{N}_{t}
$$




$$
\begin{aligned}
\hat{L}_{t}= & Z_{t-1}-0,202 Z_{t-2}+0,202 Z_{t-3}+a_{t}+0,887 a_{t-12} \\
\widehat{N}_{t}= & \bar{w}_{1}\left(-45,86 e_{t, 1}-1,837 e_{t, 2}-935400\right)+\bar{w}_{2}\left(4,686 e_{t, 1}+5,88 e_{t, 2}-30800\right)+ \\
& \bar{w}_{3}\left(-4,27 e_{t, 1}-0,8446 e_{t, 2}+229600\right)+\bar{w}_{4}\left(-1,86 e_{t, 1}-3,29 e_{t, 2}+35170\right)
\end{aligned}
$$

\section{DAFTAR PUSTAKA}

Faulina, R., dan Suhartono. 2013. Hybrid ARIMA-ANFIS for Rainfall Prediction in Indonesia. International Journal of Science and Research (IJSR) Vol. 2, Issue 2: Hal. 159-162.

Jang, J. S. R., Sun, C. T., dan Mizutani, E. 1997. Neuro Fuzzy and Soft Computing: A Computational Approach to Learning and Machine Intelligence. London: PranticeHall, Inc.

Kusumadewi, S., dan Hartati, S. 2006. Neuro Fuzzy: Integrasi Sistem Fuzzy \& Jaringan Syaraf. Yogyakarta: Graha Ilmu.

Soejoeti, Z. 1987. Materi Pokok Analisis Runtun Waktu. Jakarta: Karunika.

Tarno. 2013. Kombinasi Prosedur Permodelan Subset ARIMA dan Deteksi Outlier untuk Prediksi Data Runtun Waktu. ISBN: 978-602-14387-0-1. Prosiding Seminar Nasional Statistika UNDIP Semarang.

Tarno, Subanar, Rosadi, D., dan Suhartono. 2013. Analysis of Financial Time Series Data Using Adaptive Neuro Fuzzy Inference System (ANFIS). IJCSI Vol.10, Issue 2, No.1: Hal 491-496.

Wei, W. W. S. 2006. Time Series Analysis, Univariate and Multivariate Methods. Canada: Addison Wesley Publishing Company.

Zhang, G. P. 2003. Time Series Forecasting Using a Hybrid ARIMA and Neural Network Model. Neurocomputing, 50: Hal. 159-175. 